\title{
Implementing strategies to overcome social-ecological traps: the role of community brokers and institutional bricolage in a locally managed marine
} area

\author{
Dirk J. Steenbergen ${ }^{1}$ and Carol Warren ${ }^{2}$
}

\begin{abstract}
We examine collaborative arrangements for resource management between communities and external agencies, with a particular interest in how community-based interventions are integrated into local contexts. This timely inquiry comes in a period when participatory resource management approaches are increasingly being applied to overcome the perpetual cycles of poverty in which poor resource-dependent people find themselves, i.e., social-ecological traps. Much of the literature on social-ecological traps has focused on identifying conditions, factors, and responses that are important in, for example, alleviating systemic poverty or developing sustainable resource management systems. However, insufficient focus has been placed on understanding the practical processes by which strategies are implemented, and how these can reflexively affect the system itself. Drawing from a case study of a locally managed marine area in Indonesia, we examine the interactions between a nongovernment organization and a target community during the implementation of a fisheries management plan. Applying insights from rural development studies, we show how external interventions, designed to pull people out of social-ecological traps, are operationalized into forms that make them locally familiar and appropriate through actions of community brokers and processes of "institutional bricolage." We argue that as a consequence of implementing processes, such interventions should be expected to diverge from their initial science-based justification.
\end{abstract}

Key Words: brokers; Indonesia; institutional bricolage; locally managed marine area; mediation; social-ecological traps

\section{INTRODUCTION}

The recognized need to involve local resource user groups in the management of economically and ecologically important resource stocks has propelled participatory resource management forward as an important modus operandi for development and conservation agencies (Pomeroy 1995, UNDP 2012). Coastal zones have gained particular attention following international commitments made at the UN Ocean Conference in June 2017 to implement Sustainable Development Goal 14 on sustainable use of ocean, sea, and marine resources for development (Unger et al. 2017). In these contexts, coastal resource management projects across the Asia Pacific are increasingly being implemented under various comanagement models to deal with challenging local governance settings (Persoon et al. 2003, Pomeroy et al. 2007, Foale et al. 2013, Jupiter et al. 2014, Cohen and Steenbergen 2015). These form around collaborations between technical implementation agencies, typically conservation NGOs and local resource user groups. Practically, this sees government or NGO staff working with local community representatives to cooperatively implement appropriate interventions that "sustainabilize" human-environment resource systems (Wamukota et al. 2012).

The work plans that guide these collaborations are informed by rich bodies of science that seek to improve the way resources are governed and managed (Clifton 2009). Thinking around socialecological systems, for example, has done much to shift practice toward applying more holistic approaches that frame resource management as interactions between social and ecological systems (Berkes et al. 2002, Olsson et al. 2004). The often wicked problems around resource management (Jentoft and Chuenpagdee 2009), and the precarious situations in which poor coastal communities find themselves, have usefully been framed as social-ecological (SE) traps (Cinner 2011, Kittinger et al. 2013, Boonstra and de Boer 2014). Such traps may occur where high levels of poverty drive resource exploitation beyond sustainable levels, producing positive feedback loops in the form of higher food insecurity (Laborde et al. 2016). Diminishing catch in turn jeopardizes long-term sustenance of resource dependent people, thus threatening further descent into poverty. To avoid SE traps, and achieve key sustainability outcomes, proponents of the systems approach urge the need to strengthen local resilience and adaptive management capacity (Berkes et al. 2002, Olsson et al. 2004, Folke et al. 2005, Carpenter and Brock 2008). Much of the attention in this body of work has therefore focused on understanding the systems and their interactive dynamics (Ostrom 2009, McGinnis and Ostrom 2014), and on identifying considerations that technical interventions (and project designs) need to account for to overcome poverty traps (Cinner et al. 2012, Lade et al. 2017).

Little attention, however, is given to more practical matters of implementation of these ideas and how influential these very processes can be in altering the social system and achieving positive outcomes (or otherwise). Recruitment of community collaborators, for example, has been shown to significantly influence levels of participation across different community groups, in turn determining how benefits are distributed, conflicts are resolved, and ultimately how much support the intervention gains locally (Steenbergen and Visser 2016). In their more holistic conceptualization of poverty trap dynamics, Haider et al. (2018) identify key aspects influencing trap dynamics, including in particular external drivers, in addition to cross-scale interactions, path dependencies, and social-ecological diversity. They consider that development interventions themselves can potentially emerge as such external drivers and counterintuitively, can contribute to the creation and persistence of poverty among poor resource users. For example, loan interventions aimed at diversification can reduce resource exploitation, but in turn may leave recipients in debt, risking downward spiral into further poverty and more 
intensive resource extraction. Critical perspectives on development and conservation practice as a significant factor influencing trap dynamics, can be useful for an inquiry into how external interventions affect a community's ability to overcome SE traps.

In practice, the failure of conservation and development projects to address sustainability challenges is often associated with noncompliance or insufficient community support and/or interest, rather than faulty science (Christie 2004). With many case studies showing how resource users find themselves in SE traps that lock them into cycles of poverty and resource degradation (van Oostenbrugge et al. 2004, Bunce et al. 2009, Cinner 2011), interventions appear to be repeatedly misfiring. It is a timely consideration therefore to devote more attention to the processes by which some of these interventions are implemented. Better understanding is required of how actions, negotiations, and relationships among people involved in such implementation processes affect or alter the system itself, regardless of the science behind the intervention. This requires a reflective perspective on the process of implementation and in doing so a critical examination of a priori project design. Boonstra et al. (2016:886) propose that, "explanation and conceptualization of the feedback process between response and opportunities (or between 'agency' and 'structure') are major themes in social sciences ... and can be used ... to better understand why and how SE traps are transformed or reproduced."

Perspectives from anthropology, development studies, and critical institutionalism therefore offer enriching insights into how translation of project objectives into desired impact often hinges on how effectively it integrates into existing socially complex networks of relationships, accountabilities, and interests (Brosius 2006). In noting that external projects are largely informed by dominant policy narratives (Clifton and Foale 2017, Steenbergen et al. 2017a), understanding the agency of project benefactors is imperative. Building on the recognition that the social-political fabric of communities highly influences resource-use practices (Prescott et al. 2015), we argue that thinking must be extended to include an appreciation that these relationships also form critical vehicles for change. Interactions between project managers and community representatives critically determine how projects operate locally, and whether common understanding across disciplines, worldviews, cultures, and social status distinctions is achieved.

With this study we seek to show how externally facilitated project implementation in itself is a system altering process, regardless of the predefined objective of an intervention. We are therefore primarily interested in understanding how development and conservation interventions are delivered, and come to impact upon pathways out of SE traps, rather than the common focus on what is delivered to do so. We focus on the role of local facilitating agents ("brokers") who are able to translate project resources into something that is locally salient and, in that process, facilitate local structural adjustments ("institutional bricolage"), which may or may not align with the initial project objectives.

\section{Critical institutionalist perspectives}

Literature on commons management has largely been geared toward finding suitable conditions in which to build institutions that can facilitate effective resource governance (Ostrom 1990,
Wade 1994, Baland and Platteau 1996, Ostrom et al. 2002). In that respect it formed foundational work that later fed into systems thinking around natural resource management (Berkes et al. 2002). These perspectives, however, worked on a general assumption that institutions can be constructed or engineered to fit a particular objective given the right conditions. A critical institutionalist perspective challenges these assumptions. In her work on communal water resource management in East Africa, Cleaver (2001) argues for an "institutional bricolage" approach that recognizes the often ad hoc, informal, and multivalent aspects of decision-making processes. She builds her fundamental criticism of the functionalist notion that "crafting of institutions suggests that specific institutions are deliberately developed for particular functions," and suggests in contrast that "collective action institutions may be multipurpose, management may be both intermittent and robust, an integral part of social relations and a negotiated result of active assemblage" (Cleaver 2001:29 [emphasis in original]). As the French word bricolage suggests, the concept conceives of institutions and their agents as creative and resourceful in their use of what is available (Cleaver 2012), and much more ad hoc than institutional engineering might suggest. She defines the conception of bricolage to mean the "adaptive processes by which people imbue configurations of rules, traditions, norms and relationships with meaning and authority. In doing so they modify old arrangements and invent new ones but innovations are always linked authoritatively to acceptable ways of doing things" (Cleaver 2012:34). For the purposes of this study, Cleaver's attention to the dynamic and contextual functioning of local institutions provides a fruitful way of looking at complex structural influences on resources management.

\section{Agency perspectives}

To develop a deeper appreciation for the individual's role, work in development sociology also provides constructive insights. Norman Long's (2001) actor-oriented approach to studying development practice proposes an analytical framework based on the premise that social life is heterogeneous and multifaceted. $\mathrm{He}$ argues that people rarely act alone and social action is never an entirely ego-centered endeavor. Actions are embedded in networks of people (Fafchamps 2006), influenced by routine, and bounded by structural convention and culture (Arce and Long 2000). At the same time, although meanings and values may be culturally constructed they are differentially applied by individuals (Long 2001). Long notes that if we are to understand the continuing failures of development (and conservation) programs we need to focus on the social process and not just on the structural outcomes.

In examining an NGO's engagement with one community, we focus on the social spaces where people from different backgrounds meet in negotiations over resource management. Our primary interest is twofold, namely in how interactions take place and who acts in these spaces. Therefore, processes of mediation, and the role of brokers, are important to clarify conceptually. Where Long identifies acts of mediation to be carried out by generic mediators, we borrow De Sardan's (2005) more nuanced conceptualization of brokers. He understands the process of mediation to involve "[i]nteractions between the developmentalist configuration and ... populations ..., [which] develop via discreet passageways, relays, extended or restricted 
networks of transmission, interfaces. This is fundamentally a process that relies on mediation, which proceeds through a wide range of multiple, embedded, overlapping, intertwined mediations" (De Sardan 2005:166). Mediation thus requires particular skills that can negotiate social-ecological complexity and translate ideas, concepts, and information from a contextually alien form to one that is understandable and usable.

Brokers can thus be understood to be community members that function (or are taken to function) as representatives of the community, or a particular constituency, and in that role maintain useful relationships across social spaces (James 2011, MorganTrimmer 2014). In the context of project implementation, they represent the local social recipients as interlocutors of information, support, and financial aid structures. It is important to note that brokers do not operate as objective, unattached, and neutral agents, nor do individuals simply appear in these positions. Brokers constantly negotiate private as well as public interests and accordingly may seek to exploit outside resources for the wider community and/or for themselves in their role as intermediaries (Mosse and Lewis 2006). Emerging from the social context of the communities they are a part of, implies that dynamic power relations and complex social orders affect who arrives in these positions and how they function in them (Mosse and Lewis 2006, James 2011). Such dynamics can be highly influential (Crona et al. 2010) and are thus important to consider when seeking to instigate changes to a system.

\section{METHODS}

For this study we examine how implementation of a communitybased conservation project integrates into existing landscapes of interests, governance, and local ways of doing things. We follow the key social paths of relationships that span the interface between technical agencies and the community, through which project resources and information are passed. Using a mixed method qualitative approach (Johnson and Onwuegbuzie 2004), we draw from a case study of a locally managed marine area (LMMA) in Indonesia to make explicit how external (albeit participatory) projects are accommodated by local brokers who are recruited to an outside agenda. These agents must be understood to operate in an ambivalent space where they remain part of the local social system while trying to negotiate and adapt the ideas, principles, and concepts of sustainable resource management into the community sphere. Our case study approach offers rich insights into the kind of social dynamics taking place behind project implementation and provides in-depth perspectives that large-sampled quantitative studies over broad contexts may otherwise lack (Stake 1995).

\section{Study site: Tanimbar Kei, Southeast Maluku}

Tanimbar Kei island is located in the Kei Archipelago that falls under the administration of Southeast Maluku district in Maluku province, eastern Indonesia (Fig. 1). In part because of the island's remoteness, the estimated 500 people living across the $>120$ households making up the island's only community (Kecamatan Kei Kecil Barat 2010) all show high dependence on the immediate marine environment for their livelihoods. Harvests from seaweed farming, shark fishing, and copra production provide necessary income to pay for children's off-island secondary education, healthcare costs, dietary supplements like rice, and other household expenses (Steenbergen et al. 2017b). Given the lack of cool storage and distance from the market, small scale fishing activities contribute largely to subsistence needs. The most significant fishing pressure is from seasonal outside fishers participating in economically attractive fisheries around Tanimbar Kei. Participation in these fisheries requires skills and gear that Tanimbar Kei fishers at large do not have nor show interest in acquiring. Despite evidence of the reaches of globalization, accelerated by the expansion in recent years of mobile telephone networks connecting the island to the mainland, the community still upholds a very strong customary (adat) system. This system is strongly dictated by traditional law and social structures in the community (for more detailed accounts of traditional social structures of Tanimbar Kei refer to Barraud 1979).

Fig. 1. Map of the Kei Islands in Southeast Maluku district (Indonesia), indicating the location of Tanimbar Kei as the study site (embedded box).

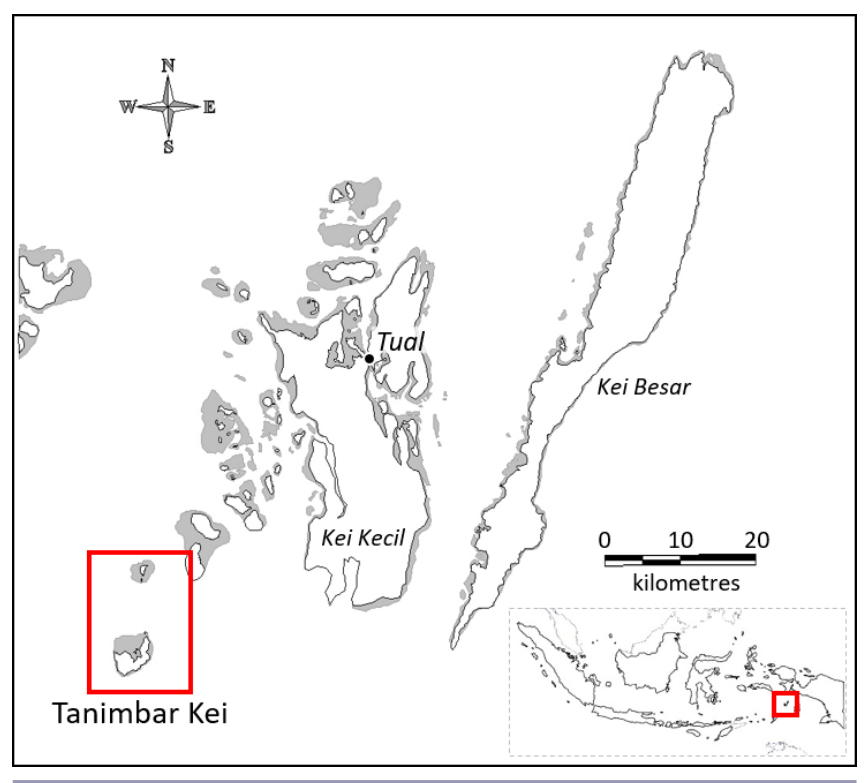

Since 2006 the community on Tanimbar Kei has been in collaboration with an external NGO under a comanagement arrangement. Through technical facilitation by the NGO the community project has established a resource management plan around a legally recognized LMMA. The community project is led by a conservation team, which in turn is headed by three project coordinators. Like all the conservation team members, the coordinator positions can only be occupied by members of the community. Such management principles were agreed upon in early project inception and planning meetings involving external facilitation by NGO staff. The process of appointment follows consultation with the community at open meetings, in addition to deliberation with the members of the traditional council. Since the inception of the community project, coordinators have rotated; however, all coordinators have been linked through direct lineage, or are married into, one of the 23 families that make up the founding customary kinship structure in Tanimbar Kei (Steenbergen 2016). This traditional core group of families in turn makes up about $75 \%$ of the community. So representing the cultural norms and rules embodied by this traditional core stands 
as a fundamental responsibility of the coordinators' leadership positions in the project.

\section{Data collection}

This research built on the lead author's long-term engagement since 2009 with the small community on the island of Tanimbar Kei (Steenbergen 2016, Warren and Visser 2016, McCarthy et al. 2017, Steenbergen et al. 2017b). For this particular study, data collection took place between 2014 and 2017 during frequent visits to the island, ranging between two to four weeks. The ethnographic research approach applied qualitative mixedmethods to data collection organized over three phases. Given the key focus on agency of particular people, data collection in the latter phases involved information-oriented sampling (Flyvbjerg 2006), with interview subjects selected on the basis of their known role as either technical facilitators or community representatives. All interviews were carried out in Bahasa Indonesia, in the company of research assistants from the village for appropriate cultural and local language facilitation.

The first phase sought to (i) understand the local governance context of the village and (ii) identify what interests and values people associated with the community LMMA project. Randomized household surveys $(n=43)$ enquired about participation, leadership, and governance in the village, and also included questions to gauge the extent of villagers' general knowledge of the project. These gave us a cross section background understanding of village attitudes and local dynamics. These were followed by a first round of in-depth semistructured interviews carried out with key informants from the village $(n=6)$ selected based on their involvement as leaders in the LMMA village project, including the three brokers. These interviews inquired into who were influential decision-making figures in the community, what local interests were most important at a community level, and whether these interests were perceived to be compatible, or in competition, with those of external actors. Participant observations during community meetings and project implementation activities provided important supplementary data on how decisions were made and what kind of local interests were perceived to be important.

The second phase of data collection focused on what various outcomes the community project had delivered to date as perceived by different key implementing actors, including the facilitating NGO staff and the interface actors (brokers). First, a review was carried out of documented project outputs in the form of community-based management plans, and published and unpublished reporting material from the NGO. Six main project objectives of the fisheries management component were identified, including (i) ensuring fishery management capacity, (ii) enforcement of spatial fishery management / access rules, (iii) enforcement of fishing quotas, (iv) enforcement of gear restrictions, (v) enforcement of species targeting, and (vi) management of income from fisheries management. These were used as a reference to gauge differences between intended outcomes versus actual outcomes. This fed into a second round of in-depth semistructured interviews that were carried out with the community interface brokers $(\mathrm{n}=3)$ and staff from the NGO $(\mathrm{n}=3)$. These questioned how the project implementation processes addressed both parallel and conflicting interests between the NGO and the community.
The third phase involved a final series of in-depth dataverification interviews $(n=6)$ with previously interviewed key informants operating in the community-NGO interface, following analysis of data from the first and second phase. These interviews were structured around questions of "how negotiations over competing interests had led to particular project outcomes" and "if local resource use patterns had consequently changed." Respondents were asked their opinion on whether project outcomes had adequately represented local needs and had addressed the objectives of sustainable management and poverty alleviation.

\section{RESULTS}

\section{Resource governance in Tanimbar Kei}

Like many small island communities, the people of Tanimbar Kei maintain a collective existence in the face of considerable shocks and shifts to the social-ecological system they are a part of. Strong mutual support systems and mechanisms for food security and insurance have become integral parts of the customary value system on the island. Intricate links with the sea and the social environment around them are evident in many of the rituals in Tanimbar Kei and clearly indicate the high value associated with both natural and cultural resources. With the exception of an outlying enclave of about 15 households made up of migrant families, most of Tanimbar Kei's households subscribed to the traditional rules, norms, and conduct that make up the central customary system. Importantly, those migrant households held no claim to land ownership, and showed very little interest and low participation in community-level action and decision making.

Respondents identified three main institutions in the community that determined the direction of leadership and decision making: village administration, traditional (adat), and religious councils. The village administration and traditional council in particular assume the most leverage, the former for its connection to central government and the latter for its representation of local customary beliefs and norms. Although these two platforms at times appeared difficult to distinguish for respondents, by and large the village administration deals with matters of internal and external governance as part of national structures of government administration. Conversely, the traditional council tends to deal with matters of local social order. Over the years individuals have come to occupy positions simultaneously within both these structures and therefore play dual leadership roles based on democratic selection or inherited rights, or both. With the customary social system having such prominence in day-to-day village life, it forms a strong local identity and holds a central normative position based upon which the village leadership functions. The traditional council embodies customary principles and operationalizes these by taking advantage of links to external resources through village administration.

The locally managed marine area comanagement arrangement With the establishment of the LMMA community project, access to marine resource stocks is controlled by community leaders using legitimate authority to sanction offenders under a subdistrict government endorsement. Enabling this is a set of community resource management regulations that guide how resources are accessed and managed. Regulations stipulate limits 
on gear use and catch, prohibitions on capture of particular species, and restrictions on spatial access to fishing grounds. These were locally formulated with facilitation of the NGO and signed by leaders from the village government, traditional council, and religious council. The NGO's facilitation extended to gaining legal endorsement for these rules by subdistrict government, which at the same time confirmed local customary management rights.

The community LMMA project drew from these regulations in applying a suite of interventions and management measures that are geared toward developing more sustainable use of resources. These ranged from developing an environmental curriculum in the village primary school and management planning for a seasonal flying-fish fishery, to gazetting no-take areas for economically important marine resources, e.g., trochus shell and reef fish, and monitoring their population growth. The participatory nature of the project resulted in collaborative planning, implementation, and evaluation, whereby the NGO sought to align its facilitative role with local interests, culture, and norms. This participatory management arrangement provided opportunity for the project to assume a local shape that reflected interests on the ground. As presented in the next section, this shaping produced outcomes that deviated from initial expected project outcomes for fisheries management.

\section{Competing interests in fisheries management}

In the important fisheries management component of Tanimbar Kei's LMMA project, interventions were developed to progress the sustainable management of fishery resources around the island, with the particular objective of providing livelihood opportunities for Tanimbar Kei people over the long term. The process of developing these interventions involved deliberation between external NGO staff and community brokers, who became the local coordinators, each representing their constituency's set of interests.

In their technical advisory role external project staff presented Western science-based paradigms around sustainable fisheries management. One NGO staff noted, their primary objective was to develop community-based fisheries management systems that are "beneficial in the short term for those who rightfully depend on the resource stocks... [and to] ensure that will remain the case in the future." An important aspect of that protection implicitly involved understanding and managing the ecological components, to which much of the fisheries science speaks. Inputs from project staff were therefore geared largely toward technically guiding the design of interventions so that they could have predictably positive ecological impacts. Furthermore, standing relatively separate from the community, external NGO project staff were somewhat less predisposed to local social influences than, for example, the community brokers were. This meant a second role in the NGO's engagement was to provide some form of oversight, to ensure mechanisms were in place for fair distribution of benefits and equal opportunity to voice needs from across the community.

The three conservation coordinators, who functioned as brokers between the external project and their community constituency, represented the major community interests. A primary concern from the perspective of the Tanimbar Kei representatives was that the autonomy of the community be acknowledged and strengthened, not solely in relation to the specific collaboration with the project on fisheries, but as much for its potential impact on the broader cultural and administrative landscape. There was a significant concern among traditional elders and other village leaders that the customary system could be undermined with the increasing encroachment of globalization. Neighboring island communities, that in the past also drew from customary systems as Tanimbar Kei still does, have since seen many of their traditions and cultural practices diluted in what many villagers referred to as modern or cash-driven lifestyles.

Next to preserving their cultural capital and way of life, the drive toward securing some form of autonomy was also to counter external threats that people felt could strip them of their rightful ownership over the land and sea around the island. Villagers often referred to cases elsewhere in Indonesia they had heard of where foreign investors obtained concessions, taking authority away from communities. Elder respondents also recalled past experiences with top-down government structures that failed to recognize any form of local ownership. Gaining security over access and ownership into the future therefore formed a primary motivation for engagement with external conservation agencies.

A secondary objective the community coordinators mentioned as part of their role in collaborations with external project staff was their duty to guide external resources and knowledge into the village so as to ensure effectivity. As one coordinator noted when asked what he felt his role was as a mediator between the community and the project, "We know who is lazy, who works hard and who is reliable ... so we can best advise which responsibility to give to whom." Although such steering is undoubtedly partial to the coordinators' subjective judgements, coordinators noted they were often asked by external NGO staff during meetings who from the community would be best appointed for particular tasks.

The mediating role of the community coordinators was reflected further in the adjustments to fisheries management interventions during implementation. Table 1 presents the outcomes of some of the main interventions of the fisheries management component, following deliberation of competing external versus internal interests voiced by project staff on one hand and the community coordinators as representatives of Tanimbar Kei people (the brokers) on the other.

\section{DISCUSSION}

Our analysis of results addresses the notion that conservation and development interventions themselves may contribute to the creation or maintenance of poverty and feedback to entrench social-ecological traps (Haider et al. 2018). In their framework on human responses to SE traps, Boonstra et al. (2016) incorporate desires, opportunities, and abilities in addition to the common factor of adaptive capacity as conditions affecting behavioral responses to resource decline and persisting poverty. This provides a useful departure point to broaden our understanding of how interventions end up being implemented locally, namely by taking into account local interests, opportunities to induce change, and abilities to guide decision making and implementation. The outcomes in each part of the community's fisheries management plan demonstrate different brokering actions. In some cases, it is evident that negotiations between project and community interests occurred and 
Table 1. Overview of mediated program outcomes resulting from differentiated interests between technical facilitating staff and the community representatives as part of a locally managed marine area (LMMA) program in Tanimbar Kei, eastern Indonesia. Fisheries management objectives developed to escape the social-ecological trap appear in the furthest right column.

\begin{tabular}{ll}
\hline \hline Objective & $\begin{array}{l}\text { Project interests driven by NGO } \\
\text { facilitation }\end{array}$ \\
\hline \#1: Ensuring fishery & $\begin{array}{l}\text { Provide enabling conditions to } \\
\text { develop local capacity to manage } \\
\text { fisheries so as to safeguard fishery } \\
\text { resources and support local } \\
\text { livelihoods, particularly to enable } \\
\text { resilience to changing conditions, } \\
\text { e.g., climate change. }\end{array}$ \\
& $\begin{array}{l}\text { Implementation of an annual } \\
\text { rotational fishery access plan across } \\
\text { \#2: Enforcement of } \\
\text { spatial fishery }\end{array}$ \\
management / access & control fishing pressure. \\
rules &
\end{tabular}

\section{Community interests driven by community Mediated Outcomes} LMMA coordinators

Strengthen rights over land and sea as
rightful custodians, in the face of concern about loss of ownership rights from foreign investment and government control.

To control access of outside fishers; With exception to small dynamic customary closures (spatially and temporally variable), for which compliance is high because of the social consequences dictated by custom, such internal control over the LMMA is less applicable. Restrictions on access to those fixed fishery zones do not assume enforcement under customary law, that supports rightful access to its seas as a whole for Tanimbar Kei descendants.

Outsiders must adhere to local fishery quotas.

No destructive fishing practices permitted by anyone (insider or outsider). fisher, no destructive fishing practices allowed, e.g. bombing, fish traps, etc., adherence to gear restrictions, e.g., minimum mesh Regardless of the origin of the fisher, no endangered species may be targeted (as defined by national law); otherwise sanctions apply.

\#6: Management of income from fisheries management

Regardless of the origin of the fisher, all catch must be within set quotas, otherwise sanctions apply.

Restrictions on species consumption are determined by traditional beliefs and taboos, and vary from community-wide prohibition to family-based (or even individual) taboo.

Financial management can be carried out by traditional leadership or village government. sanctioned. techniques. apprehended. size nets, otherwise sanctions apply.
Ensure proper financial management, e.g., set up bank account and transparent Use of funds suggested to primarily (1) recycle back into the community fisheries program to work toward a financially independent program, and (2) to contribute to community-wide livelihood improvement. management.

A right-based fisheries management (RBFM) approach was applied. Since 2008 Tanimbar Kei gained subdistrict-level authority that explicitly mandates management by the Tanimbar Kei customary community over 40,000 hectares of land and sea territory.

The territory was defined and managed as one region with no practical enforcement of internal distinctions between zones in the territory (despite mention in management documents). Sanctions imposed on outsiders only.

Use of funds suggested to primarily recycle into the community to address peoples'

needs, with allocation managed by traditional leadership.

Only outsiders have been apprehended; there has yet to be a community member

Outsiders have been apprehended, often based on their use of illegal gear/

Fishing pressure by villagers was relatively low, so gear has not had to be

Traditional dietary taboos persisted.

Species under national protection were still caught for customary adat (traditional) rituals, e.g., turtle, and these cases were tolerated given this (traditional, subsistence) intention.

A bank account was opened and regular income from fisher licenses and sanctions were deposited, with monthly bank

statements displayed on community notice board.

For the first four years accumulated funds were not used, because of unclear rules and sensitivity to potential misuse. Since then funds have been used on a case by case basis to help cover education expenses of households and to provide aid, e.g., food provisions, to poor households. Importantly, the NGO has urged for representation beyond traditional leaders in decision making about allocation, so as to avoid biased allocations (resulting in involvement of village government staff). eventuated in midground outcomes. Other cases show how interventions appear in management documentation as part of achieving an intended outcome, however are only partially enforced by community leaders in their implementation. These strategies show how factors that make interventions sustainable, i.e., helping people overcome the precarious SE trap they are in, are as much dependent on being technically accurate as they are socially compatible (Cumming 2018). We explicate these different brokering strategies below.

\section{Brokering strategies}

The deliberate application of rights-based fisheries management (RBFM) by the project (objective \#1 in Table 1), as an appropriate fisheries management approach aligns closely with Tanimbar 
Kei's interest to strengthen their autonomous rights over their traditional land and sea territory. The first step in achieving this, namely gaining government endorsement to legitimize management rights over their territory, represented significant progress for both external project staff and community coordinators, albeit for different reasons. For project staff gaining local tenure rights was important, in part as a common principle for legitimating community resource management (Ostrom 2009, Allison et al. 2012), but also because it laid a foundation on which more effective enforcement for fisheries management could be developed, given that the community could now sanction and license out fishing rights. For the Tanimbar Kei community this formal recognition represented strengthening of their custodianship over a far broader spectrum than just fisheries management. As one conservation team member argued, "it is now for the world to know that these are our [Tanimbar Kei] waters, ... our traditional right is written in government documents." RBFM, being their chosen approach to guide fisheries management, eventually drove the implementation of the island's fisheries management plan (objective \#2 in Table 1), largely because of its perceived potential to strengthen both sets of interests. Another example of where a negotiated middle ground was reached involved the issue of endangered species targeting (objective \#5 in Table 1). External project staff argued for total prohibition of capture. The community consensus, however, showed resistance to such strict regulation, in part because some species have always been traditionally consumed as part of important social events. Brokering by the community coordinators eventually led to latitude in the prohibition of endangered species capture. Revised regulation allowed for turtles to be captured and consumed as long as they were not traded, but rather used exclusively for consumption as part of a traditionally associated ceremony.

Where interventions were formulated that included elements that did not find local support, only partial enforcement was evident. Most striking in Tanimbar Kei was the implementation adjustments around restrictive measures that selectively targeted subjects of regulation who were socially least affiliated with the Tanimbar Kei community. For example, in enforcing gear restrictions and fishing quotas (objectives \#3 and 4 in Table 1), outside fishers from other regions in Indonesia, as well as outside fishers from villages closer to Tanimbar Kei, were readily apprehended and sanctioned. Sanctioning fellow fishers from Tanimbar Kei has to date not occurred. Prohibiting fellow community members from fishing in a particular area or sanctioning them for exceeding a quota appeared to conflict directly with their perceived right to fish as recognized under Tanimbar Kei's common customary law. The community coordinators in these cases adapted implementation of those particular measures so that fishing practices by fellow Tanimbar Kei islanders were deemed beyond the scope of fisheries regulations. This is not written into the management plan, but appeared to have been accepted by the community management team, and tolerated by the external facilitating NGO staff given there was no corrective response.

Further evidence of brokerage between conservation agency and community interests occurred in deliberations about financial management of income from the fisheries management component. External project staff strongly argued for particular checks and balances to be put in place to ensure fair distribution of benefits across the whole village. These were explicit measures to allow benefit distribution to extend beyond the majority traditional core group made up of households from the founding 23 families. It led to the opening of a bank account instead of local cash management by the traditional leaders or village government, information dissemination regarding the balance of funds in the communal account, and incorporation of community representatives beyond traditional leaders in decision making about allocation of funds to aid poor households. The brokers in this case allowed for external facilitators to have significant say in establishing local financial management processes.

The question of why the voice of external project staff appeared more readily taken up in this matter versus previous examples (where brokers took it upon themselves to adjust or implement measures to suit local social conditions) is interesting. A likely explanation is the sensitivity associated with managing money. Past experiences and widespread accounts of corruption of government project funds has made dealing with communal funds a highly volatile and sensitive matter. The fact that funds were not used in the first four years of accumulation supports this claim. One coordinator explained that "the money was growing in the bank but we were scared to use it because people might think we are using it for ourselves ... it is better that someone else decides how to use it." Allowing external agents to take partial lead in advising how to manage funds meant local leaders were less likely to be blamed for malpractices. This echoes documented experiences elsewhere where such aspects are seen to be prone to socio-political biases if dictated entirely by immersed actors (Fritzen 2007, Ferrol-Schulte et al. 2015, Warren and Visser 2016).

\section{Influence of external engagements}

The above brokering processes and adjustments to interventions illustrate firsthand the agency that people have in steering a system (Long 2001), in combination with structural shifts and institutional bricolage that arise from collective negotiations over time (Cleaver 2012). Frick-Trzebitzky et al.'s (2017:63) analysis of the effects of institutional dynamics on human vulnerability to flood risk reveal similar "mechanisms by which bricolage takes place, namely by tinkering, transformation and reinvention." In that context they specifically refer to the way shifting interests and priorities reflected differences between actors' perceptions and experiences of risk, in much the same way the mediated form of Tanimbar Kei's LMMA reflected multiple negotiations.

Applying language of Boonstra et al. (2016)'s SE trap framework, our mediation cases show that the brokering ability of coordinators led in some instances to the partial amendment of interventions and in other instances to the partial enforcement of them. Such modifications allowed for sufficient accommodation of opposing desires to make implementation acceptable. The establishment of the community LMMA project thus provided opportunity to address the challenges people faced but also to channel particular priority interests. Although the amendments have resulted in an accommodating governance regime, the question remains to what extent the prospects for addressing the root challenges to overcome the SE trap they were initially developed for have been compromised. 


\section{CONCLUSION}

We set out to show how external project implementation in itself can produce trap altering processes (Boonstra et al. 2016, Haider et al. 2018), and used a case study of a community-based fisheries management program establishing an LMMA to show how brokers facilitate institutional adjustments. The outcomes from fisheries management interventions (Table 1) demonstrate the agency of these brokers in finding means to make foreign concepts acceptable locally, and in other cases to adjust implementation of potentially conflicting measures so as to maintain public support. Through such agency new ideas have gained presence and value among older ones, to move the continual institutional growth in the community in a particular, possibly new, direction. That new direction is influenced in part by principles of sustainable fisheries management given impetus by the external project staff. However, of perhaps greater importance, the new direction reflects a strengthening of particular existing interests and values that have found compatibility with project aims that lie in the inherent motivation and drive toward autonomy and maintenance of the cultural fabric of the community. Such amalgamations reflect strongly the rejigging and ongoing patchwork that Cleaver (2012) refers to with the concept of institutional bricolage. The dynamic processes involved in implementation appear then to form feedback loops that alter arrangements and interactions, similar to those identified in interactions between components of socialecological systems. The act of intervening with the intention of achieving a directed impact in itself then appears to produce significant change, in this case, well beyond predefined project bounds.

The experiences of implementing fisheries management around the community LMMA shows how particular measures are shaped from theoretical conception, only to be reshaped during their practical implementation so as to gain salience in a local social-ecological context. Recognizing this, reinforces that a priori design of resource management strategies simply cannot be rigid (Janssen and Ostrom 2006, Armitage et al. 2008). At best these strategies can set out guide posts that indicate the general right pathway out of a SE trap, but by no means can prescribe that path. Therefore focus on process and continual recognition of feedback loops that occur as interventions gain local shape is imperative in guiding how people can escape SE traps as far as possible on their terms (Boonstra et al. 2016). It is promising that the literature on fisheries comanagement already recognizes opportunity in hybridization of practices that draw from both Western science-based principles and customary practices (Pomeroy and Andrew 2011, Cohen and Steenbergen 2015). Technical fisheries managers need to expand their conservation and development brief in order to achieve synergistic accommodations with local norms, practices, and beliefs. To do so they must match their approach with those of a specific kind of local broker (Cleaver's "institutional bricoleur") who is sufficiently grounded locally to be able to juxtapose, translate, and construct a common agenda in a process aimed at institutional progression with which local people can identify.

Beyond building on a theory of how SE traps develop and how poor people can escape them, we have argued for the need to direct attention to processes rather than solely to outputs. Implementation processes are all too often still taken for granted in theory (Cleaver 2001), in the same way that projects are still all too often judged for success by predefined outputs. Considering the dynamics illustrated in the case study, conservation and development initiatives stand to gain more support at local level by aligning with the social and political relationships people already have, rather than promoting an abstract and narrow moral justification and technical model for doing things sustainably. Investment in identifying appropriate brokers and enabling them to facilitate processes of institutional bricolage will do much to bring together technical knowledge of how to escape SE traps with better understandings of how things get done on the ground.

Responses to this article can be read online at: http://www.ecologyandsociety.org/issues/responses. php/10256

\section{Acknowledgments:}

The authors are grateful for the funding support provided under a North Australia Marine Research Alliance (NAMRA) postdoctoral grant (NAMRA-2-2014, administered through Charles Darwin University) and an Australian Research Council Discovery grant (DP0880961). We furthermore sincerely thank the special feature editors and two anonymous reviewers for their constructive comments that helped to improve the manuscript. Finally, we would like to thank in-country research assistants, and all our respondents who kindly participated to provide useful insights and data for the study.

\section{LITERATURE CITED}

Allison, E. H., B. D. Ratner, B. Åsgård, R. Willmann, R. Pomeroy, and J. Kurien. 2012. Rights-based fisheries governance: from fishing rights to human rights. Fish and Fisheries 13(1):14-29. http://dx.doi.org/10.1111/j.1467-2979.2011.00405.x

Arce, A., and N. Long. 2000. Anthropology, development and modernities: exploring discourses, counter-tendencies and violence. Routledge, London, UK. http://dx.doi.org/10.4324/9780203450895

Armitage, D., M. Marschke, and R. Plummer. 2008. Adaptive comanagement and the paradox of learning. Global Environmental Change 18(1):86-98. http://dx.doi.org/10.1016/j.gloenvcha.2007.07.002

Baland, J.-M., and J.-P. Platteau. 1996. Halting degradation of natural resources: Is there a role for rural communities? Food and Agriculture Organization of the United Nations, Clarendon Press, and Oxford University Press, Oxford, UK. http://dx.doi. org/10.1093/0198290616.001.0001

Barraud, C. 1979. Tanebar-evav: Une société de maisons tournée vers le large. Cambridge University Press, Cambridge, UK. http:// dx.doi.org/10.4000/books.editionsmsh. 5791

Berkes, F., J. Colding, and C. Folke, editors. 2002. Navigating social-ecological systems: building resilience for complexity and change. Cambridge University Press, Cambridge, UK. http://dx. doi.org/10.1017/CBO9780511541957

Boonstra, W. J., E. Björkvik, L. J. Haider, and V. Masterson. 2016. Human responses to social-ecological traps. Sustainability Science 11(6):877-889. http://dx.doi.org/10.1007/s11625-016-0397- 
Boonstra, W. J., and F. W. de Boer. 2014. The historical dynamics of social-ecological traps. Ambio 43(3):260-274. http://dx.doi. org/10.1007/s13280-013-0419-1

Brosius, J. P. 2006. Common ground between anthropology and conservation biology. Conservation Biology 20(3):683-685. http:// dx.doi.org/10.1111/j.1523-1739.2006.00463.X

Bunce, M., L. Mee, L. D. Rodwell, and R. Gibb. 2009. Collapse and recovery in a remote small island: a tale of adaptive cycles or downwards spirals? Global Environmental Change 19(2):213-226. http://dx.doi.org/10.1016/j.gloenvcha.2008.11.005

Carpenter, S. R., and W. A. Brock. 2008. Adaptive capacity and traps. Ecology and Society 13(2):40. http://dx.doi.org/10.5751/ ES-02716-130240

Christie, P. 2004. Marine protected areas as biological successes and social failures in Southeast Asia. American Fisheries Society Symposium 42:155-164.

Cinner, J. E. 2011. Social-ecological traps in reef fisheries. Global Environmental Change 21(3):835-839. http://dx.doi.org/10.1016/ j.gloenvcha.2011.04.012

Cinner, J. E., T. R. McClanahan, M. A. MacNeil, N. A. J. Graham, T. M. Daw, A. Mukminin, D. A. Feary, A. L. Rabearisoa, A. Wamukota, N. Jiddawi, S. J. Campbell, A. H. Baird, F. A. Januchowski-Hartley, S. Hamed, R. Lahari, T. Morove, and J. Kuange. 2012. Comanagement of coral reef social-ecological systems. Proceedings of the National Academy of Sciences 109 (14):5219-5222. http://dx.doi.org/10.1073/pnas.1121215109

Cleaver, F. 2001. Institutional bricolage, conflict and cooperation in Usangu, Tanzania. Institute of Development Studies (IDS) Bulletin 32(4):26-35. http://dx.doi.org/10.1111/j.1759-5436.2001. mp32004004.x

Cleaver, F. 2012. Development through bricolage: rethinking institutions for natural resource management. Routledge Taylor and Francis Group, New York, New York, USA.

Clifton, J. 2009. Science, funding and participation: key issues for marine protected area networks and the coral triangle initiative. Environmental Conservation 36(2):91-96. http://dx.doi.org/10.1017/ $\underline{\mathrm{S} 0376892909990075}$

Clifton, J., and S. Foale. 2017. Extracting ideology from policy: analysing the social construction of conservation priorities in the coral triangle region. Marine Policy 82:189-196. http://dx.doi. org/10.1016/j.marpol.2017.03.018

Cohen, P. J., and D. J. Steenbergen. 2015. Social dimensions of local fisheries co-management in the coral triangle. Environmental Conservation 42(03):278-288. http://dx.doi.org/10.1017/ $\underline{\mathrm{S} 0376892914000423}$

Crona, B. I., M. Nyström, C. Folke, and N. Jiddawi. 2010. Middlemen, a critical social-ecological link in coastal communities of Kenya and Zanzibar. Marine Policy 34 (4):761-771. http://dx.doi.org/10.1016/j.marpol.2010.01.023

Cumming, G. S. 2018. A review of social dilemmas and socialecological traps in conservation and natural resource management. Conservation Letters 11(1):e12376. http://dx.doi. org/10.1111/conl.12376
De Sardan, J. P. O. 2005. Anthropology and development: understanding contemporary social change. Zed Books, London, UK.

Fafchamps, M. 2006. Development and social capital. Journal of Development Studies 42(7):1180-1198. http://dx.doi. org $/ 10.1080 / 00220380600884126$

Ferrol-Schulte, D., P. Gorris, W. Baitoningsih, D. S. Adhuri, and S. C. A. Ferse. 2015. Coastal livelihood vulnerability to marine resource degradation: a review of the Indonesian national coastal and marine policy framework. Marine Policy 52:163-171. http:// dx.doi.org/10.1016/j.marpol.2014.09.026

Flyvbjerg, B. 2006. Five misunderstandings about case-study research. Qualitative Inquiry 12(2):219-245. http://dx.doi. org/10.1177/1077800405284363

Foale, S., D. Adhuri, P. Aliño, E. H. Allison, N. Andrew, P. Cohen, L. Evans, M. Fabinyi, P. Fidelman, C. Gregory, N. Stacey, J. Tanzer, and N. Weeratunge. 2013. Food security and the coral triangle initiative. Marine Policy 38(1):174-183. http://dx.doi. org/10.1016/j.marpol.2012.05.033

Folke, C., T. Hahn, P. Olssen, and J. Norberg. 2005. Adaptive governance of social ecological systems. Annual Review of Environmental Resource 30:441-473. http://dx.doi.org/10.1146/ annurev.energy.30.050504.144511

Frick-Trzebitzky, F., R. Baghel, and A. Bruns. 2017. Institutional bricolage and the production of vulnerability to floods in an urbanising delta in Accra. International Journal of Disaster Risk Reduction 26:57-68. http://dx.doi.org/10.1016/j.ijdrr.2017.09.030

Fritzen, S. A. 2007. Can the design of community-driven development reduce the risk of elite capture? Evidence from Indonesia. World Development 35(8):1359-1375. http://dx.doi. org/10.1016/j.worlddev.2007.05.001

Haider, L. J., W. J. Boonstra, G. D. Peterson, and M. Schlüter. 2018. Traps and sustainable development in rural areas: a review. World Development 101:311-321. http://dx.doi.org/10.1016/j. worlddev.2017.05.038

James, D. 2011. The return of the broker: consensus, hierarchy, and choice in South African land reform. Journal of the Royal Anthropological Institute 17(2):318-338. http://dx.doi.org/10.1111/ j.1467-9655.2011.01682.x

Janssen, M. A., and E. Ostrom. 2006. Governing social ecological systems. Pages 1466-1509 in L. Tesfatsion and K. L. Judd, editors. Handbook for computational economics. Elsevier, Amsterdam, The Netherlands.

Jentoft, S., and R. Chuenpagdee. 2009. Fisheries and coastal governance as a wicked problem. Marine Policy 33(4):553-560. http://dx.doi.org/10.1016/j.marpol.2008.12.002

Johnson, R. B., and A. J. Onwuegbuzie. 2004. Mixed methods research: a research paradigm whose time has come. Educational Researcher 33(7):14-26. http://dx.doi.org/10.3102/0013189X033007014

Jupiter, S. D., P. J. Cohen, R. Weeks, A. Tawake, and H. Govan. 2014. Locally-managed marine areas: multiple objectives and diverse strategies. Pacific Conservation Biology 20(2):165-179. http://dx.doi.org/10.1071/PC140165 
Kecamatan Kei Kecil Barat. 2010. Kei Kecil barat dalam angka. [Western Kei Kecil in numbers]. Badan Pusat Statistik, Central Board of Statistics, District of Maluku Tenggara, Langgur, Indonesia.

Kittinger, J. N., E. M. Finkbeiner, N. C. Ban, K. Broad, M. H. Carr, J. E. Cinner, S. Gelcich, M. L. Cornwell, J. Z. Koehn, X. Basurto, R. Fujita, M. R. Caldwell, and L. B. Crowder. 2013. Emerging frontiers in social-ecological systems research for sustainability of small-scale fisheries. Current Opinion in Environmental Sustainability 5(3-4):352-357. http://dx.doi. org/10.1016/j.cosust.2013.06.008

Laborde, S., A. Fernández, S. C. Phang, I. M. Hamilton, N. Henry, H. C. Jung, A. Mahamat, M. Ahmadou, B. K. Labara, S. Kari, M. Durand, B. Mark, P. Scholte, N. Xiao, R. Ziebe, and M. Moritz. 2016. Social-ecological feedbacks lead to unsustainable lock-in in an inland fishery. Global Environmental Change 41:13-25. http://dx.doi.org/10.1016/j.gloenvcha.2016.08.004

Lade, S. J., L. J. Haider, G. Engström, and M. Schlüter. 2017. Resilience offers escape from trapped thinking on poverty alleviation. Science Advances 3(5):e1603043. http://dx.doi. org/10.1126/sciadv. 1603043

Long, N. 2001. Development sociology: actor perspectives. Routledge, London, UK. http://dx.doi.org/10.4324/9780203398531

McCarthy, J. F., D. J. Steenbergen, C. Warren, G. Acciaioli, G. Baker, A. Lucas, and V. Rambe. 2017. Community driven development and structural disadvantage: interrogating the social turn in development programming in Indonesia. Journal of Development Studies 53(12):1988-2004. http://dx.doi. org/10.1080/00220388.2016.1262024

McGinnis, M. D., and E. Ostrom. 2014. Social-ecological system framework: initial changes and continuing challenges. Ecology and Society 19(2):30. http://dx.doi.org/10.5751/ES-06387-190230

Morgan-Trimmer, S. 2014. 'It's who you know': community empowerment through network brokers. Community Development Journal 49(3):458-472. http://dx.doi.org/10.1093/cdj/bst049

Mosse, D., and D. Lewis. 2006. Theoretical approaches to brokerage and translation in development. Pages 1-26 in D. Lewis and D. Mosse, editors. Development brokers and translators: the ethnography of aid and agencies. Kumarian Press, Bloomfield, Connecticut, USA.

Olsson, P., C. Folke, and F. Berkes. 2004. Adaptive comanagement for building resilience in social-ecological systems. Environmental Management 34(1):75-90. http://dx.doi.org/10.1007/s00267-003-0101-7

Ostrom, E. 1990. Governing the commons: evolution of institutions for collective action. Cambridge University Press, Cambridge, UK. http://dx.doi.org/10.1017/CBO9780511807763

Ostrom, E. 2009. A general framework for analyzing sustainability of social-ecological systems. Science 325:419-422. http://dx.doi.org/10.1126/science.1172133

Ostrom, E., T. Dietz, N. Dolsak, P. C. Stern, S. Stovich, and E. U. Weber, editors. 2002. The drama of the commons. National Academy Press, Washington, D.C., USA.
Persoon, G. A., D. M. E. van Est, and P. E. Sajise, editors. 2003. Co-management of natural resources in asia: a comparative perspective. Nordic Institute of Asian Studies, Copenhagen, Denmark.

Pomeroy, R. S. 1995. Community-based and co-management institutions for sustainable coastal fisheries management in Southeast Asia. Ocean \& Coastal Management 27(3):143-162. http://dx.doi.org/10.1016/0964-5691(95)00042-9

Pomeroy, R. S., and N. L. Andrew, editors. 2011. Small-scale fisheries management: frameworks and approaches for the developing world. CAB International, Wallingford, UK. http://dx. doi.org/10.1079/9781845936075.0000

Pomeroy, R. S., J. Parks, R. Pollnac, T. Campson, E. Genio, C. Marlessy, E. Holle, M. Pido, A. Nissapa, S. Boromthanarat, and N. Thu Hue. 2007. Fish wars: conflict and collaboration in fisheries management in Southeast Asia. Marine Policy 31 (6):645-656. http://dx.doi.org/10.1016/j.marpol.2007.03.012

Prescott, J., J. Riwu, D. J. Steenbergen, and N. Stacey. 2015. Governance and governability: the small-scale purse seine fishery in Pulau Rote, eastern Indonesia. Pages 61-84 in S. Jentoft and R. Chuenpagdee, editors. Interactive governance for small-scale fisheries: global reflections. Springer, Cham, Switzerland. http:// dx.doi.org/10.1007/978-3-319-17034-3 4

Stake, R. E. 1995. The art of case study research. Sage, Thousand Oaks, California, USA.

Steenbergen, D. J. 2016. Strategic customary village leadership in the context of marine conservation and development in southeast Maluku, Indonesia. Human Ecology 44(3):311-327. http://dx.doi. org/10.1007/s10745-016-9829-6

Steenbergen, D. J., J. Clifton, L. E. Visser, N. Stacey, and A. McWilliam. 2017a. Understanding influences in policy landscapes for sustainable coastal livelihoods. Marine Policy 82:181-188. http://dx.doi.org/10.1016/j.marpol.2017.04.012

Steenbergen, D. J., C. Marlessy, and E. Holle. 2017b. Effects of rapid livelihood transitions: examining local co-developed change following a seaweed farming boom. Marine Policy 82:216-223. http://dx.doi.org/10.1016/j.marpol.2017.03.026

Steenbergen, D. J., and L. E. Visser. 2016. Caught between mediation and local dependence: understanding the role of nongovernment organisations in co-management of coastal resources in eastern Indonesia. Anthropological Forum 26(2):115-137. http://dx.doi.org/10.1080/00664677.2016.1148012

Unger, S., A. Müller, J. Rochette, S. Schmidt, J. Shackeroff, and G. Wright. 2017. Achieving the sustainable development goal for the oceans. Institute for Advanced Sustainability Studies, Potsdam, Germany.

United Nations Development Programme (UNDP). 2012. Community-based marine management foundation, Indonesia. Equator initiative case studies series, New York, New York, USA.

van Oostenbrugge, J. A. E., W. L. T. van Densen, and M. A. M. Machiels. 2004. How the uncertain outcomes associated with aquatic and land resource use affect livelihood strategies in coastal communities in the Central Moluccas, Indonesia. Agricultural Systems 82(1):57-91. http://dx.doi.org/10.1016/j.agsy.2004.01.002 
Wade, R. 1994. Village republics: economic conditions for collective action in south India. Institute for Contemporary Studies, San Francisco, California, USA.

Wamukota, A. W., J. E. Cinner, and T. R. McClanahan. 2012. Comanagement of coral reef fisheries: a critical evaluation of the literature. Marine Policy 36(2):481-488. http://dx.doi.org/10.1016/ j.marpol.2011.09.001

Warren, C., and L. E. Visser. 2016. The local turn: an introductory essay on leadership, elite capture and good governance in Indonesian conservation and development programs. Human Ecology 44:277-286. http://dx.doi.org/10.1007/s10745-016-9831- 